\title{
AN EVAlUATION OF THE FUNCTIONALITY AND DELIVERY OF WEBSITES OF pOlitical parties in South Africa
}

\author{
Authors: \\ Maria Crossland ${ }^{1}$ \\ Wallace Chigona ${ }^{1}$

\begin{abstract}
Affiliations:
${ }^{1}$ Department of

Information systems,

University of Cape Town,

Cape Town, South Africa
\end{abstract} \\ Correspondence to: \\ Wallace Chigona \\ email: \\ wallace.chigona@uct.ac.za

\section{Postal address:} \\ Department of Information \\ Systems, Faculty of \\ Commerce, University of \\ Cape Town, Private Bag, \\ Rondebosch 7701, South \\ Africa
}

\section{Keywords:}

Information dissemination; information reception; online campaigning; political parties; voter communication

\section{Dates:}

Received: 19 Nov. 2009

Accepted: 12 May 2010

Published: 09 Nov. 2010

How to cite this article: Crossland, M. \& Chigona, W., 2010, 'An evaluation of the functionality and delivery of websites of political parties in South Africa', SA Journal of Information Management 12(1), Art. \#453, 5 pages. DOI: 10.4102/sajim.v12i1.453

\section{This article is available} at:

http:/ / www.sajim.co.za

(c) 2010. The Authors. Licensee: OpenJournals Publishing. This work is licensed under the Creative Commons Attribution License.

\section{ABSTRACT}

The political communication environment worldwide has been transformed by the Internet with websites providing opportunities for affordable information dissemination and reception. Internationally, a party contesting an election without a website seems impossible today. This exploratory study examines the use of websites by political parties during the 2009 South African elections and investigates the functionality offered by the websites as well as how effectively this functionality is delivered. The study analysed the websites of both large and small political parties. It is worth noting that in spite of the lower Internet penetration rates in South Africa, the majority of political parties contesting the 2009 elections had websites. The study shows that the websites of the larger parties generally offer more functionality than those of the smaller parties, supporting the view of 'normalisation' of party competition in cyberspace. However, an analysis of the delivery of the content does not confirm the normalisation effects.

\section{INTRODUCTION}

The Internet has transformed the political communication environment worldwide with websites providing opportunities for affordable information dissemination and reception (Gibson \& Ward 2002; Stanyer 2006). In the developing world it is unthinkable for a party to contest an election without Internet presence; in fact, most parties now consider a website a necessary tool for campaigning (Stanyer 2006; Conway \& Dorner 2004). A recent prominent example of the use of the Internet for political campaigning has been the Barack Obama presidential campaign. Obama has been referred to as 'America's first Internet president' due to the manner in which his campaign team exploited information technology to interact with electorate during the campaign period (Greengard 2009:16).

Early studies of Internet usage for political campaigning focused on the United States of America (USA) (Gibson \& Ward 2000). However, subsequent studies have been conducted in, amongst others, the United Kingdom (UK) (Jackson 2007), Japan (Tkach-Kawasaki 2003), Australia (Gibson \& Ward 2002), New Zealand (Conway \& Dorner 2004), Italy (Vaccari 2008) and Germany (Schweitzer 2005). There have been recommendations that such research should be extended into longitudinal studies and similar analyses should be undertaken in other countries to build a broader picture of the use of websites by political parties (Conway \& Dorner 2004; Schweitzer 2005).

Exploratory studies on the use of Internet for South African political parties have highlighted the level of Internet penetration as a crucial difference between South Africa and developed countries, such as the UK and the USA. Whilst over 55\% of adults in the UK and USA have access to the Internet (Smith, 2009; Lusoli \& Ward 2005), only approximately one in ten South Africans have access (Lefko-Everett 2009). However, this is still a significant proportion of the people who vote (Lusoli 2005; News24 2008). Whilst most campaigning will continue to utilise traditional media, such as television and print, there is a growing opportunity for South African political parties to use electronic media to reach certain groups of supporters (Lefko-Everett 2009).

Using the 2009 elections as a case study, this exploratory study examines how effectively South African political parties use the Internet. It examines the functionality offered by the websites available as well as how effectively the websites deliver these functions. By looking at the functions available online, insight is gained as to whether the channel was used to reach a wide audience, to provide information quickly and cost effectively and whether or not it was used as a way of interacting with voters. However, the usefulness of the website will depend on the effectiveness of the delivery of the functionality as the content will count for little if it is difficult for the target audience to use. Performing the study in South Africa, results in findings that are more applicable to other developing nations than previous studies, which have typically been conducted in developed countries (such as the US, UK, Japan, Australia, Italy and Germany) and do not factor in the low rates of Internet penetration prevalent in African countries.

\section{LITERATURE REVIEW}

\section{Politics and the Internet}

Politicians have always used a wide range of methods to communicate with people in their quest to get elected. Since the 1990s, candidates have used websites to publicise their views, garner support and fund their campaigns in the US (Greengard 2009; Schweitzer 2005). Early Internet technology only provided one way communication, allowing candidates to report events and make partisan appeals. However, modern technology (i.e. blogs, wikis and social networking sites) allows for interaction with the electorate (Stanyer 2006; Greengard 2009). Barack Obama's presidential campaign leveraged the opportunities offered by the Internet to communicate with people and garner support for his campaign. The campaign attracted approximately two million Facebook supporters, collected the email addresses of over 13 million people and the Obama.com website had more than two million registered users 
(Greengard 2009). The campaign team began using the Internet early on and saw it as a way to make contact with people who were not engaged in the political process unfolding at the time (Elsworth 2008). In the lead up to the election, $74 \%$ of American Internet users used the Internet to access election related news items or to get involved in the political process (Smith 2009).

The use of the Internet as a campaign tool offers benefits to both the electorate and political parties. One of the benefits of using technology for the electorate is that the Internet enables free flow of information as the information is no longer controlled by the political parties, authority structures or media organisations (Elsworth 2008). Internet campaigns are driven by the consumers rather than the producers (Lusoli \& Ward 2005; Lusoli 2005). The Internet also adds transparency to campaign politics by providing the public with a platform to debate the claims made by political parties (Elsworth 2008). Internet search engines make it easy for the public to validate politicians' claims. For campaigners, the availability of information on the Internet means that if used correctly, political parties can deliver 24 hour access to instantly updated information and campaign news, as well as instant rebuttals to attacks from other parties (Lusoli \& Ward 2005; Lusoli 2005). The Internet also offers a cost effective channel through which political parties can reach voters.

However, this technology also has the potential to damage a party's image. Unless a party has a clear purpose behind their online activities, it is possible that the online activities may project a negative image of the party (Gibson \& Ward 2000). Whilst the new level of transparency is positive for the electorate and the political parties, there is always a danger that insignificant issues can easily be magnified. Consequently, politicians using technology to boost their campaigns could find themselves open to more criticism than those who do not (Hartley 2009). It can be said, therefore, that offering more participative options on the party website, could open political parties to damaging abuse without necessarily providing a significant benefit (Gibson, Margolis, Resnick \& Ward 2003). The ease with which unverified, doctored and incorrect information can be posted on the Internet also raises new challenges for political candidates (McGinity 2007). Furthermore, seeing that the information is always available, political websites are a convenient option for information seekers (Lusoli \& Ward 2005).

Previous research has examined the possibility that the Internet provides an opportunity for equalised competition between parties regardless of party size or resources available (Gibson \& Ward 2002). The 'normalisation' view suggests that the inequalities seen in real world campaign activity are simply replicated on the Internet as financial constraints limit the funding available for the development of a website (Schweitzer, 2005), therefore, larger parties will perform better in cyberspace than smaller parties (Vaccari 2008; Gibson et al. 2003). The opposing view suggests that the low cost of establishing a website, the lack of external editorial control and the appeal of independent non-establishment views to young people are all factors that could be beneficial to smaller and less established parties (Gibson \& Ward 2002). Apart from party size, a divide is also seen between parliamentary and non-parliamentary parties (Gibson et al. 2003).

Another interesting point in looking at the use of the Internet by political parties is the demographic profile of the potential users of such websites. It has been noted that the youth are more likely to use the political party websites. Obama received strong support from youth and first-time voters and credit for much of this support has been given to the campaign's use of the Internet to reach these voters. Young Internet users are more likely to vote than young people not using the Internet (Lusoli \& Ward 2005). Further, it has been noted that websites with a multimedia format are attractive to young people (Gibson \& Ward 2002; Lusoli 2005).
The role the Internet has played for political parties in different parts of the world is affected, to an extent, by the prevailing political landscape. For instance, the role of the Internet in terms of politics in Japan is different from the role the Internet plays in democratic nations with multiparty systems and few media controls (Tkach-Kawasaki 2003). Despite government restrictions placed on the use of websites for political campaigning in Japanese elections, opposition parties and newer parties in particular are making extensive use of electronic media. Conversely, in Russia where one party is also dominant, websites tend to be uninformative with limited functionality and an amateurish look and feel (Oates 2008).

\section{The goals of political party websites}

According to Gibson and Ward (2000), political party websites have five basic goals:

- information provision - dissemination of information about the party's identity and policies

- campaigning - attempts by parties to recruit voters

- resource generation - raising funding and registering new members

- networking - building and strengthening links within the party and with external bodies through discussion applications and hyperlinks

- promoting participation - encouraging people to engage in the political process by raising awareness of events and issues and offering opportunities for interactive communication.

The inherent properties of the Internet offer political parties an alternative channel for reaching potential voters and information seekers. Increased bandwidth and new functionality mean that large volumes of information can be made available to an audience in a short time, in a manner that appears personalised and offers opportunities for interaction (Gibson et al. 2003). However, research has shown that the available functions are not being utilised and the Internet is primarily used by political parties for information dissemination (Jackson 2007).

\section{A framework for evaluating political websites}

The criteria used to evaluate political websites are broadly based on those used to evaluate general Internet resources (Conway \& Dorner 2004). Gibson and Ward (2000) proposed a framework using 43 evaluation criteria to study the functionality and delivery of websites. Functionality focuses on the broad direction and type of information and communication flow (ICF). The direction of the information could be upward (from organisation to user), downward (from user to organisation) and lateral (outwards from the organisation to other bodies, or inwards to structures within the organisation). Two-way or interactive ICFs are characterised by input from users or from the organisation with either side expecting a response from the other. The delivery component of the framework examines the effectiveness with which the functionality is delivered. The criteria used to evaluate delivery are focused on data retrieval and presentation, considering only the most basic aspects of navigability, accessibility, freshness and visibility and are focused on older Internet technology capabilities that are now widely available on most websites.

If the Internet is to be considered a communication tool rather than just a data retrieval tool, modifications need to be made to the Gibson and Ward (2000) model (Oates 2008). Gibson et al. (2003) adapted the framework for use in their comparative study on Internet campaigning in the USA and UK; they added criteria such as conference information, privacy policy, article library and volunteer solicitation. In terms of delivery, Oates (2008) suggests augmenting the model to allocate points for participatory items, such as the number of events listed, whether users can post to a website (e.g. using blogs) and whether users are able to access social networking sites. However, the original model still works effectively for evaluating political websites in 
countries such as the UK and Russia where political websites tend to be less dynamic (Oates 2008).

The Gibson et al. framework and its derivatives have been used in a number of studies. For instance, for a study of political party websites used in the 2006 Italian election, Vaccari's (2008) evaluation used three main groupings of variables:

- information which included user- and party-initiated information supply

- participation, including online interaction, resource mobilisation

- professionalism in terms of multimedia usage, accessibility, update frequency and accessibility.

The study confirmed the findings of earlier studies, that is, that party websites are still used mainly for information exchange rather than establishing a participatory environment. Schweitzer (2005) studied websites of German political parties in the leadup to the country's 2002 elections. In addition to evaluating functional and formal aspects of the websites (as proposed by Gibson and Ward (2000)), the study also examined the content related aspects of the websites as well as comparing online campaign activities to those being used in traditional media. An Australian study conducted outside of a pre-election campaign period found that the main function of Australian political party websites was one-way information provision with few sites taking advantage of the variety of multimedia or interactive applications available (Gibson \& Ward 2002).

Conway and Dorner (2004) used an adapted version of Gibson and Ward's (200) framework to study New Zealand's political party websites shortly after the 2002 elections in that country. The study found that, similar to the Australian and German studies, political websites were mainly used to provide information and little use was being made of the tools available to make this information more accessible. Parties in parliament provided a wider range of functions on their websites than nonparliamentary parties but there were no significant differences between the minor and major parties.

\section{CONTEXT}

\section{South African Political Process and use of the Internet}

To facilitate the understanding of the discussion, this section will give an overview of the South African political context. Parliamentary elections are held in South Africa every five years and all nationals over the age of 18 are eligible to vote. The country uses a proportional representation voting system (Government of South Africa 1996) whereby the electorate vote for a party; the number of parliamentary seats for a party is in direct proportion to the number of votes it received. A political party selects members to fill its parliamentary seats. There are two chambers of Parliament, namely the National Assembly and the Council of Provinces. Each voter casts two votes, one for the national level and one for the Provincial Assembly of the province in which they reside.

The country has no direct presidential election. It is the responsibility of parliament to vote for a president from the list of candidates nominated by the various parties in parliament. However, in practice, parties promote their presidential candidates during the campaign period.

There were 40 parties registered to contest the national and provincial elections held on 22 April 2009 in South Africa. Eleven parties contested the National Assembly election and the provincial Elections in all nine provinces. Two parties contested elections at national level only, fourteen parties took part at national level as well as in one or more (but less than nine) provinces and thirteen parties were involved at provincial level only (in one or more provinces) (IOL 2009).
TABLE 1

Websites selected for inclusion in this study

\begin{tabular}{lccc}
\hline Party Name & Level $^{\dagger}$ & Established & $\begin{array}{c}\text { Seats in } \\
\text { National } \\
\text { Assembly } \\
(\mathbf{2 0 0 7 )}\end{array}$ \\
\hline A Party & 2 & 2008 & 0 \\
African Muslim Party & 4 & 1994 & 0 \\
African National Congess (ANC) & 1 & 1912 & 297 \\
Cape Party & 4 & 2008 & 0 \\
Congress of the People (COPE) & 1 & 2008 & 0 \\
Democratic Alliance (DA) & 1 & 1959 & 47 \\
Independent Democrats (ID) & 1 & 2003 & 4 \\
Minority Front (MF) & 3 & 1993 & 2 \\
Pan African Congress of Azania (PAC) & 1 & 1959 & 1 \\
Women Forward & 3 & 2008 & 0 \\
\hline
\end{tabular}

${ }^{\dagger}$ Level indicates the level at which the party contested the 2009 elections: 1, National and all nine provinces; 2, National only; 3, National and certain provinces only; 4, Provincial only - one or more provinces.

Research on the use of the Internet amongst South African political parties is still in its infancy. There are differing views on how effectively South African political parties are using the Internet. Lefko-Everett (2009) found that prominent parties have well established websites and are actively using applications such as Facebook, Twitter and YouTube. It has been argued in the media that local politicians do not understand the value of digital media or how to use it and are unwilling to allocate funding to such initiatives (News24 2008).

\section{RESEARCH METHODOLOGY}

The websites of political parties contesting the 2009 elections were examined during April 2009. An initial list of the parties contesting the elections was obtained from the South African Government website (Provincial list of 42 parties to contest 2009 elections 2009). A web survey was then used to establish the online presence of the parties contesting the elections at national and provincial level. Of the 40 parties contesting the elections at national and/or provincial level, 29 were found to have websites. Of the parties that did not have a website, nine were contesting provincial level elections only and two were contesting at national and provincial level.

Seeing that the study was exploratory, a limited number of websites were included in the detailed study. The party websites surveyed were selected to provide a variety of, (1) large and small parties, (2) established and new parties, (3) parties contesting at national and/or provincial level as well as (4) parliamentary and non-parliamentary parties (prior to the 2009 election). Table 1 provides details of the political parties whose websites were selected for the study.

Previous research indicates that activity and updates on political websites is at its peak immediately prior to an election with a significant difference in level of activity between these times and other times (Vaccari 2008; Gibson et al. 2003). The assessment of the websites for this study was done in the week immediately after the 22 April 2009 elections.

The study used the adapted coding scheme proposed by Gibson et al. (2003) to conduct content analysis focused on the functionality and design of the political party websites. As shown in Table 2, the section of the coding scheme on functionality is divided into five sections while the coding for site delivery is based five factors.

The coding scheme used in the study includes a multimedia index which assigns a score for use of video on a website. For this study, links to YouTube were given a score of 1 . If a site provided any information in a language other than English, a positive score was given for the foreign language measure. Websites which included blogs were assigned a score of 2 for interaction. 
TABLE 2

The coding scheme for functionality and delivery

\begin{tabular}{ll}
\hline Functionality & Delivery \\
\hline Information provision & Glitz factor \\
Resource generation & Accessibility \\
Networking & Navigability \\
Participation & Freshness \\
Campaigning & Visibility \\
\hline
\end{tabular}

Due to time constraints, the websites were only examined once, which excluded frequency of update as an evaluation criterion, although it is included in the original coding scheme. The criterion assessing Wireless Access Point (WAP) enablement was also excluded from this study.

\section{FINDINGS}

\section{Website functionality}

Consistent with the literature, information provision appeared to be the main function of the web sites though it was noted that the parties were also using the Internet for resource generation. However, the full functionality of Internet applications was not being exploited by any of the parties, with the possible exception of the Democratic Alliance (DA) (Table 3). All sites provided basic party information such as policies, manifestos and values but less than half provided a party history or structure. In terms of candidate information, the websites privileged party leaders over the other candidates; seven of the ten sites provided a party leader (presidential candidate) profile but only four parties provided information about other candidates. Anecdotal evidence shows that a similar trend is observable when parties use other media for campaigning. The volume of information available varied across the political parties, but this is not reflected in the scores allocated. Conway and Dorner (2004) note that if the number of items, such as press releases or newsletters, is taken into consideration, the smaller parties often outperform the larger ones.

In terms of lateral communication, the African National Congress (ANC) was the only party to provide any partisan links; their site also included a large number of reference links to news sources and academic sites. Only the DA and the ANC had links to internal organisations. There were no links to members of parliament's own websites, which contrasts with the findings of Gibson and Ward (2000) and Conway and Dorner (2004).

With the exception of the DA's site, the communication flows are predominantly downwards and one-way. There was very little opportunity for interactive communication and participation, though most sites allowed for user comment to be submitted from the site. This trend is in keeping with previous studies and is explained by the risk posed to parties by incorrect, unsubstantiated and damaging information that could be posted on their site. The DA's site offered opinion polls, interactive blogs with a high level of input from the party and email contact details for all branches. The changes suggested by Oates (2008) would have a notable impact on scores in this category as a number of parties are making use of social networking sites such as Facebook and Twitter, but this is not reflected in the participation index.

Half of the sites surveyed offered secure online transactions for donations and online membership registration. A Party scored the maximum possible score for resource generation as the site offered online transactions for donations, membership and even for the purchase of party t-shirts. Future studies can look at the degree of use of such facilities. Although seven sites achieved a positive score for having commercial links on their pages, the only commercial link they had was to the website development company responsible for the site.

None of the sites achieved more than $30 \%$ of the possible score for campaigning and only three of the parties had a dedicated election site. The DA was the only party to use any form of negative campaigning. Conway and Dorner (2004) and Gibson and Ward's (2000) findings were similar for parties in New Zealand and Australia respectively.

The parties represented in parliament and those contesting the elections at national level had websites that offered more functionality than the non-parliamentary parties. The websites of the larger political parties (ANC, COPE and DA) were more functional than the smaller parties but the length of time since the party was established does not impact the standard of site available. The findings support the 'normalisation' view of competition between parties on the web, with the same parties being dominant on the Internet as in the traditional media.

\section{Website delivery}

The scores achieved for website style and delivery are summarised in Table 4. The large parties (ANC, COPE and DA) all achieved the same, highest score for glitz factor, as all offered the similar design and multimedia features. More than half the sites were using YouTube to provide access to party related video clips. The Independent Democrats (ID) was the only party to provide an audio-only clip in the form of a mobile phone ring tone. The size of the homepages varied, but all loaded in a reasonable amount of time.

Many of the sites scored zero for accessibility and only half of the party websites offered information in any language other than English and even that was limited to one or two documents per site. In line with suggestions made by Oates (2008), the relevance of certain criteria (such as the provision of text-only versions of websites and the use of frames) used to evaluate accessibility in this coding scheme are questionable in the light of technology developments since the framework was first proposed, in 2000.

None of the sites offered navigation tips and only the ANC and A Party included a site index. However, all had a home page icon and a fixed menu bar on all pages. The ANC scored significantly higher than any other party on visibility using a

TABLE 3 Functions of websites

\begin{tabular}{|c|c|c|c|c|c|c|c|c|}
\hline Party name & Level & Established & $\begin{array}{c}\text { Seats in } \\
\text { National } \\
\text { Assembly }\end{array}$ & $\begin{array}{c}\text { Information } \\
\text { provision }\end{array}$ & $\begin{array}{l}\text { Resource } \\
\text { generation }\end{array}$ & Networking & Participation & Campaigning \\
\hline A Party & 2 & 2008 & 0 & 6.0 & 13.0 & 1.0 & 3.0 & 2.0 \\
\hline African Muslim Party & 4 & 1994 & 0 & 5.0 & 3.0 & 6.0 & 0.0 & 0.0 \\
\hline African National Congess (ANC) & 1 & 1912 & 297 & 12.0 & 6.0 & 7.0 & 5.0 & 4.0 \\
\hline Cape Party & 4 & 2008 & 0 & 2.0 & 0.0 & 0.0 & 5.0 & 0.0 \\
\hline Congress of the People (COPE) & 1 & 2008 & 0 & 10.0 & 9.0 & 2.0 & 2.0 & 4.0 \\
\hline Democratic Alliance (DA) & 1 & 1959 & 47 & 15.0 & 9.0 & 2.0 & 15.0 & 6.0 \\
\hline Independent Democrats (ID) & 1 & 2003 & 4 & 6.0 & 8.0 & 2.0 & 3.0 & 1.0 \\
\hline Minority Front (MF) & 3 & 1993 & 2 & 7.0 & 1.0 & 0.0 & 0.0 & 1.0 \\
\hline Pan African Congress of Azania (PAC) & 1 & 1959 & 1 & 10.0 & 3.0 & 2.0 & 3.0 & 0.0 \\
\hline Women Forward & 3 & 2008 & 0 & 7.0 & 1.0 & 1.0 & 6.0 & 2.0 \\
\hline Mean score & - & - & - & 8.0 & 5.3 & 2.3 & 4.2 & 2.0 \\
\hline Possible score & - & - & - & $0-16$ & $0-13$ & $0-20$ & $\mathrm{n} / \mathrm{a}$ & $0-9$ \\
\hline
\end{tabular}


TABLE 4

Website style and delivery

\begin{tabular}{|c|c|c|c|c|c|c|c|c|}
\hline Party name & Level & Established & $\begin{array}{l}\text { Seats in National } \\
\text { Assembly }\end{array}$ & Glitz & Size(kb*) & Access & Navigability & Visibility \\
\hline A Party & 2 & 2008 & 0 & 4 & 516 & 0 & 3 & 98 \\
\hline African Muslim Party & 4 & 1994 & 0 & 1 & 94 & 0 & 2 & 74 \\
\hline African National Congess (ANC) & 1 & 1912 & 297 & 4 & 146 & 2 & 4 & 55100 \\
\hline Cape Party & 4 & 2008 & 0 & 0 & 186 & 1 & 2 & 252 \\
\hline Congress of the People (COPE) & 1 & 2008 & 0 & 4 & 185 & 2 & 3 & 713 \\
\hline Democratic Alliance (DA) & 1 & 1959 & 47 & 3 & 465 & 2 & 3 & 7520 \\
\hline Independent Democrats (ID) & 1 & 2003 & 4 & 4 & 510 & 1 & 3 & 7110 \\
\hline Minority Front (MF) & 3 & 1993 & 2 & 0 & 1216 & 0 & 2 & 187 \\
\hline Pan African Congress of Azania (PAC) & 1 & 1959 & 1 & 3 & 639 & 0 & 2 & 459 \\
\hline Women Forward & 3 & 2008 & 0 & 4 & 267 & 2 & 2 & 41 \\
\hline Mean score & - & - & - & 2.7 & 422.4 & 1 & 2.6 & 7155.4 \\
\hline Possible score & - & - & - & $0-6$ & $\mathrm{n} / \mathrm{a}$ & $0-5$ & $0-5$ & $\mathrm{n} / \mathrm{a}$ \\
\hline
\end{tabular}

measure which was based on results of a Google search for the party website URL.

The 'normalisation' view is challenged by the scores the websites received for 'Glitz' factors with A Party and Women Forward both equaling the scores of the larger parties. Overall (in terms of functionality and delivery), both websites offered extensive features that met the criteria used in this coding scheme; however, the quality of the actual information provided meant that the feature was often of little use.

\section{CONCLUSION}

This exploratory study sought to investigate the use of the Internet by political parties in South Africa. The study noted that in spite of the lower Internet accessibility rates in South Africa, $72.5 \%$ of the political parties contesting the 2009 elections have websites. According to Gibson et al. (2003), political parties do not consider the Internet an important campaign tool, rather perceiving it as a one-way information provision tool and, therefore, do not exploit the full capability the channel could offer. This study has confirmed that finding. Most of the South African political parties are using their websites exclusively for information provision rather than encouraging participation in the political process via the Internet. The ANC's website makes a large amount of information available but offers little by way of interactive communication with voters. The DA appears to have made the most of the opportunities offered by the Internet to communicate with voters.

It is often thought that the use of the Internet would allow the smaller parties to compete against the major parties. It was noted that the websites of the bigger parties generally offered more functionality than those of the smaller parties, supporting the view of 'normalisation' of party competition in cyberspace. However, there was little difference in the delivery of the content.

\section{REFERENCES}

Conway, M. \& Dorner, D., 2004, 'An evaluation of New Zealand political party websites', Information Research, 9(4), paper 196, viewed 12 April 2009, from www: http://informationr.net/ ir/9-4/paper196.html

Elsworth, C., 2008, US election 2008 fought over the Internet, viewed 20 March 2009, from www: http://www.telegraph. co.uk

Gibson, R. \& Ward, S., 2000, 'A proposed methodology for studying the function and effectiveness of party and candidate websites', Social Science Computer Review 18(3), 301-319.

Gibson, R. \& Ward, S., 2002, 'Virtual campaigning: Australian parties and the impact of the Internet', Australian Journal if Political Science 37(1), 99-129.
Gibson, R.K., Margolis, M., Resnick, D. \& Ward, S.J., 2003, 'Election campaigning on the WWW in the USA and UK: A comparative analysis', Party Politics 9(1), 47-75.

Goverment of South Africa, 2009, Provincial list of 42 parties to contest 2009 elections, viewed 12 April 2010, from http:// www.info.gov.za/speeches/2009/09030314451001.htm

Greengard, S., 2009, 'The first Internet president', Communications of the ACM 52(2), 16-18.

Hartley, D., 2009, Technology in the political arena. Certification Magazine, viewed 20 March 2009, from www: http://www. certmag.com/digital-edition/2009/02/

IOL, 2009, Two parties drop out of election race, viewed 17 April 2009, from http://www.iol.co.za/index.php?click id=13\&set_id=1\&art_id=nw20090311083945369C41618

Jackson, N., 2007, 'Political parties, the Internet and 2005 election: third time lucky?', Internet Research 17(3), 249-271.

Lefko-Everett, K., 2009, Elections and the Internet in South Africa, Idasa, viewed 14 April 2009, from http://www.idasa.org.za/ index.asp?page=output_details.asp\%3FRID\%3D1778\%26op lang\%3Den\%26PID\%3D44\%26OTID\%3D26

Lusoli, W. \& Ward, S., 2005, 'Logging on or switching off? The public and the Internet at the 2005 general election', in S. Coleman \& S. Ward (eds.), Spinning the web: Online campaigning in the 2005 general election, viewed 19 April 2010, http://www.lusoli.info/

Lusoli, W., 2005, 'A second-order medium? The Internet as a source of electoral information in 25 European countries', Information Polity 10, 247-265.

McGinity Shannon, M., 2007, 'Shaking hands, kissing babies and blogging?: The Internet and technology seek to influence politics as usual', Communications of the ACM 50(9), 21-24.

News24, 2008, SA politicians don't 'click', viewed 17 April 2009, from http://www.news24.com/News24/South_Africa/ Politics/0,2-7-12_2425875,00.html

Oates, S., 2008, From Political 'Surf' to "Turf'?: Developing website analysis to better understand the Internet as a Political Catalyst, viewed 15 April 2009, from http://www.media-politics. com/oates $\% 20$ apsa $\% 20$ pre $\% 20$ conf $\% 202008 \% 20$ aug $\% 20$ $25 \% 2008$.doc

Stanyer, J., 2006, 'Online campaign communication and the phenomenon of blogging: an analysis of web logs during the 2005 British general election campaign', Aslib proceedings, New Information Perspectives 58(5), 404-415.

Schweitzer, E.J., 2005, 'Election campaigning online: German party websites in the 2002 national elections', European journal of Communication, 20(3), 327-351.

Smith, A., 2009, The Internet's role in campaign 2008, viewed 19 April 2009, from http://www.pewInternet.org/Reports/2009/6-The-Internets-Role-in-Campaign-2008.aspx

Tkach-Kawasaki, L.M., 2003, 'Politics@Japan: Party competition on the Internet in Japan', Party Politics 9(1), 105-123.

Vaccari, C., 2008, 'Italian parties' websites in the 2006 elections', European Journal of Communication 23(1), 69-77. 